Article

\title{
Site-Specific Labeling of Proteins with Near-IR Heptamethine Cyanine Dyes
}

\author{
Chen-Ming Lin $₫$, Syed Muhammad Usama $₫$ and Kevin Burgess * \\ Department of Chemistry, Texas A \& M University, Box 30012, College Station, TX 77842, USA; \\ chen-ming_lin@tamu.edu (C.-M.L.); syed.usama@chem.tamu.edu (S.M.U.) \\ * Correspondence: burgess@tamu.edu; Tel.: +1-979-845-4345
}

Academic Editor: Maged Henary

Received: 19 October 2018; Accepted: 6 November 2018; Published: 7 November 2018

\begin{abstract}
Convenient labeling of proteins is important for observing its function under physiological conditions. In tissues particularly, heptamethine cyanine dyes (Cy-7) are valuable because they absorb in the near-infrared (NIR) region (750-900 nm) where light penetration is maximal. In this work, we found $\mathrm{Cy}-7$ dyes with a meso-Cl functionality covalently binding to proteins with free Cys residues under physiological conditions (aqueous environments, at near neutral $\mathrm{pH}$, and $37^{\circ} \mathrm{C}$ ). It transpired that the meso- $\mathrm{Cl}$ of the dye was displaced by free thiols in protein, while nucleophilic side-chains from amino acids like Tyr, Lys, and Ser did not react. This finding shows a new possibility for convenient and selective labeling of proteins with NIR fluorescent probes.
\end{abstract}

Keywords: heptamethine cyanine; protein labeling; thiol labeling; cancer targeting; vimentin

\section{Introduction}

Hydrophilic near-infrared (NIR) fluorescent dyes are valued for in-depth imaging in tissues, and heptamethine cyanines, or Cy-7 dyes, which absorb in the NIR region (700-900 nm), are amongst the most widely used [1]. Indocyanine green (ICG, Figure 1), the only FDA-approved Cy-7 dye, has been widely used in medical and clinical diagnostics [2-4].

Many applications of Cy-7 dyes require that they be covalently conjugated to, for example, antibodies, cell surface targeting peptides/biomarkers, and small molecule substrates. This is often achieved by modifying Cy-7 derivatives with coupling functionalities such as maleimide, succinimide esters, isocyanates, or sulfonyl halides. The challenge with strategies like this is balancing the demands of experimental convenience with selectivity towards targeted amino acid types. Extensive modifications to $\mathrm{Cy}-7$ dyes can also alter their solubility and photophysical properties [5].

Figure 1 shows dyes featured in this study. Probes of this type, i.e., with a 1-chloro-2,6disubstituted cyclohexane (i.e., MHI-148, IR-780, IR-783, and DZ-1) [6-8], are known for their tumor localizing properties [9-12]. Therefore, these Cy-7 dyes are potential carriers of cytotoxic payload for combined cancer targeted therapy and imaging [13-16]. In our research in this area, we happened to make a surprising finding regarding such a conjugation process. Specifically, when investigating in vitro reactions and cell lysates featuring MHI-148, it was found to covalently bind to several proteins with high selectivity as evidenced by gel electrophoresis and NIR imaging at around $800 \mathrm{~nm}$.

We hypothesized that the meso-Cl of MHI-148 was substituted by nucleophilic functional groups of amino acids (Cys, Ser, Tyr and Lys) of proteins. This paper provides data to support this hypothesis and understand the selectivity. 


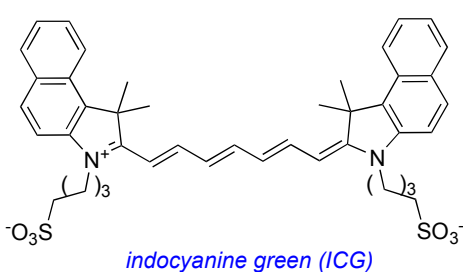

(a)

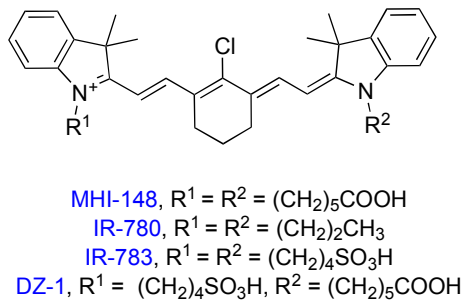

(b)

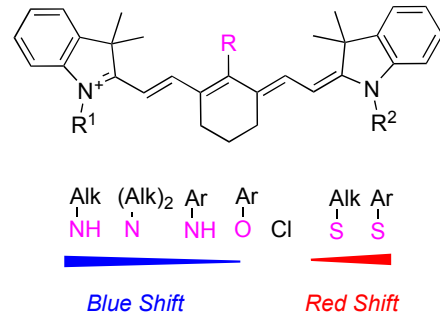

(c)

Figure 1. Structures of: (a) ICG; (b) cancer-tissue-targeting Cy-7 dyes and their meso-substituted derivatives; and (c) graphical representation of the effects of meso-substitution on electronic spectra.

\section{Results and Discussion}

\subsection{Syntheses of Amino-Acid-Substituted Cy-7 Dyes}

Reactions under controlled conditions were used to test if nucleophilic substitution of the chloride of MHI-148 possibly occurred in DMF solvent. Thus, several amino acids with different nucleophilic side-chains ( $N$-acetyl-L-cysteine, $N$-acetyl-L-tyrosine, $N \alpha$-acetyl-L-lysine, $\mathrm{N \varepsilon}$-acetyl-L-lysine, and L-proline) were reacted with MHI-148 under conditions that were varied to force the reactions to proceed. The corresponding amino-acid-substituted $\mathrm{Cy}-7$ dyes were indeed formed (Scheme 1); these were isolated, characterized (see supplementary materials for NMR and mass spectrometry), and later used as standards for comparison of high-performance liquid chromatography (HPLC) retention times. Serine was excluded from these experiments because alcohol hydroxyl groups are known to not substitute the meso-Cl without complications [17-20].

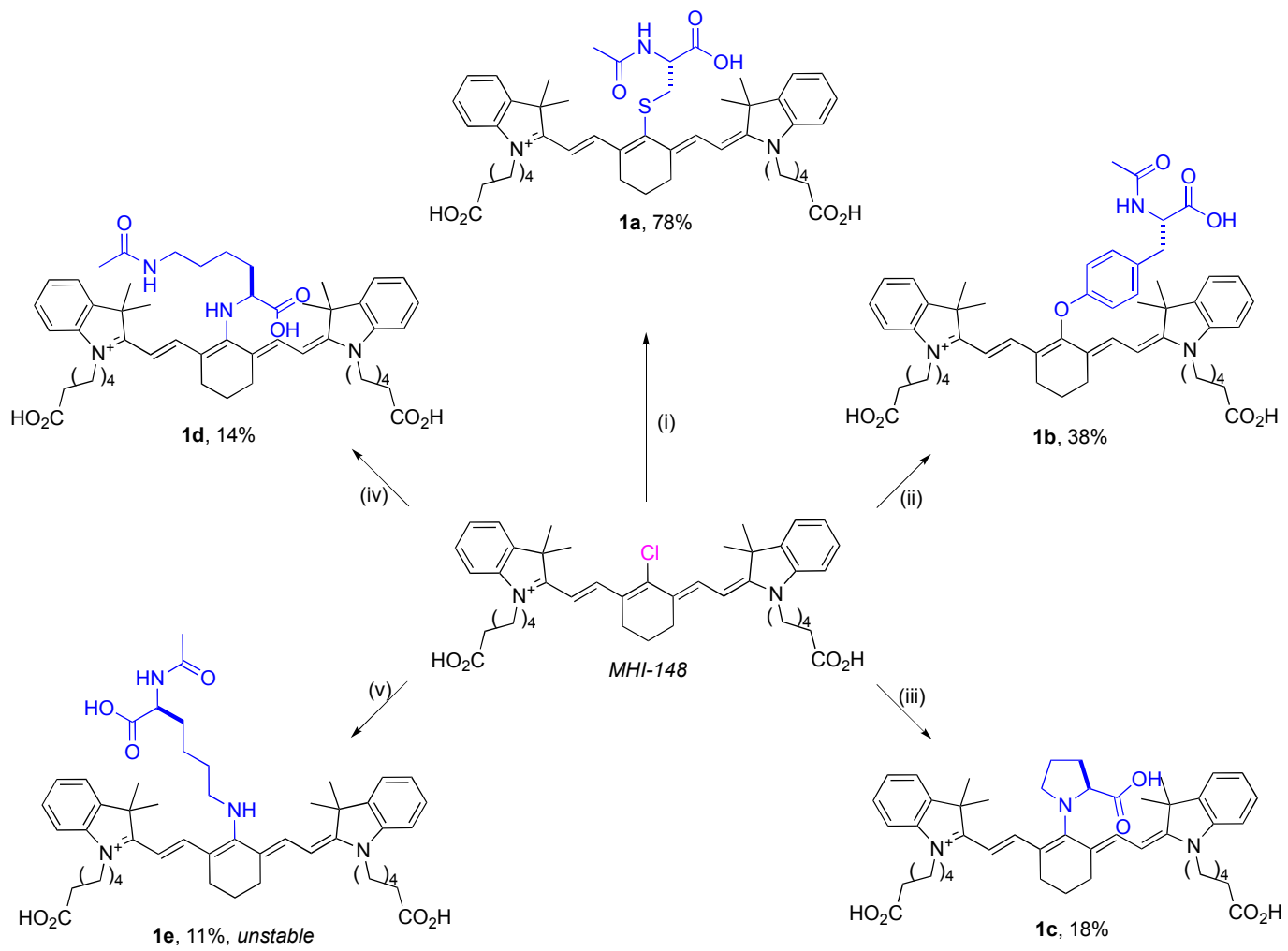

Scheme 1. Preparation of amino-acid-substituted Cy-7 dyes. (i) $\mathrm{N}$-acetyl-L-cysteine (1 eq.), ${ }^{\mathrm{i}} \mathrm{Pr}_{2} \mathrm{NEt}$ (1.5 eq.), DMF, $25^{\circ} \mathrm{C}, 1 \mathrm{~h}$ (ii) $\mathrm{N}$-acetyl-L-tyrosine (1 eq.), NaH, DMF, $25^{\circ} \mathrm{C}, 18 \mathrm{~h}$ (iii) proline ( 1 eq.), ${ }^{\mathrm{i}} \mathrm{Pr}_{2} \mathrm{NEt}$ (1 eq.), DMF, $60{ }^{\circ} \mathrm{C}, 2 \mathrm{~h}$ (iv) $\mathrm{Ne}$-acetyl-L-lysine (1 eq.), ${ }^{\mathrm{i}} \operatorname{Pr}_{2} \mathrm{NEt}$ (1 eq.), DMF $/ \mathrm{H}_{2} \mathrm{O}, 60{ }^{\circ} \mathrm{C}, 20 \mathrm{~h}$ (v) $\mathrm{N} \alpha$-acetyl-L-lysine (1 eq.), ${ }^{\mathrm{i}} \mathrm{Pr}_{2} \mathrm{NEt}\left(1 \mathrm{eq}\right.$.), $\mathrm{DMF}, 60{ }^{\circ} \mathrm{C}, 20 \mathrm{~h}$. 
$N$-Acetyl-L-cysteine was the most reactive nucleophile of the five amino acids studied. In the presence of Hünig's base, MHI-148 was completely converted to the thiol-substituted product within $1 \mathrm{~h}$ at $25^{\circ} \mathrm{C}$ in DMF (0.1 M 1:1 dye:Cys-derivative, LC-MS analyses). Four other amino acid nucleophiles studied required a stronger base (Tyr) and/or elevated temperatures (Pro and Lys), and even then, a significant amount of unreacted MHI-148 was observed after several hours. $N \alpha$-Acetyl-L-lysine reacted faster than those three, giving the substituted product 1e, which can be isolated by reversed-phase flash chromatography; however, significant decomposition was observed (color change from blue to pink) in organic solvents after only $20 \mathrm{~min}$. The instability caused by delocalization of a lone pair of elections by primary amine at meso position is also reported by other groups [21,22]. Overall, this data indicated the meso-Cl substitution reactivity was thiol $>$ phenol $>2^{\circ}$ amine $>1^{\circ}$ amine, which corresponds to the observations in the literature [23]. At this stage, we did not know if these reactivities would also be observed in aqueous media, but preferential conjugation of MHI-148 to Cys residues seemed more likely.

\subsection{Optical Properties of Amino-Acid-Substituted Cy-7 Dyes}

Figure 2 shows absorbance and fluorescence of compounds 1a-d in $10 \mathrm{mM}$ PBS buffer. The $S$ - or O-substituted compounds (1a and $\mathbf{1 b}$ ) had absorbance and fluorescence spectra similar to those of MHI-148. Significant red-shifts of absorbance and fluorescence were observed for both $N$-substituted Cy-7 dyes (1c and 1d), which have been attributed [24,25] to conjugation of the nitrogen lone pair with the Cy-7 core. Interestingly, the peaks for the $N$-substituted products are significantly broader, implying more vibrational fine structures than the $S$ - or $O$-substituted products [26].

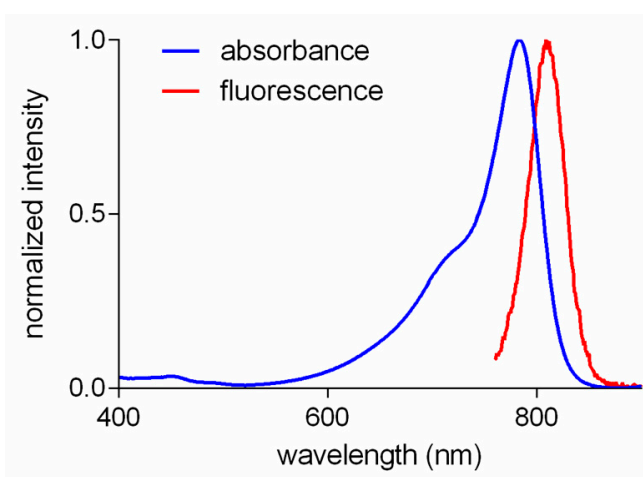

(A)

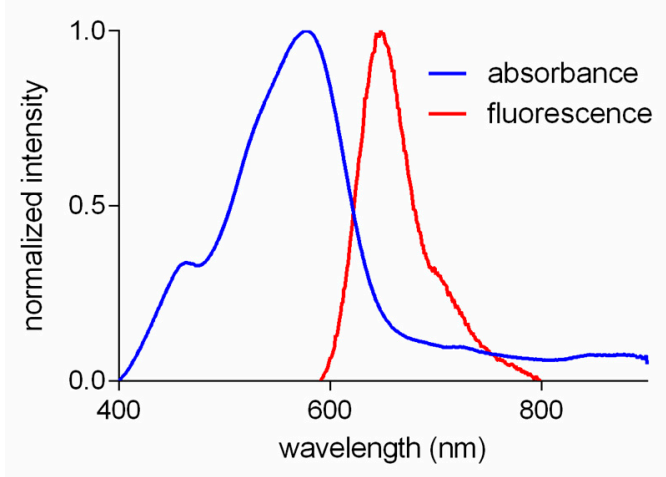

(C)

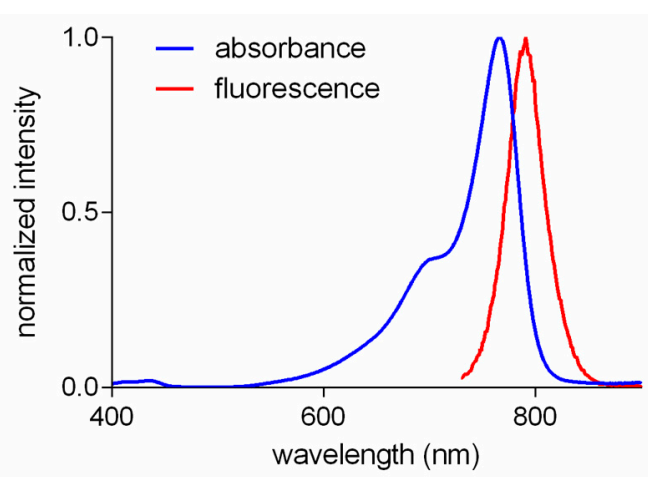

(B)

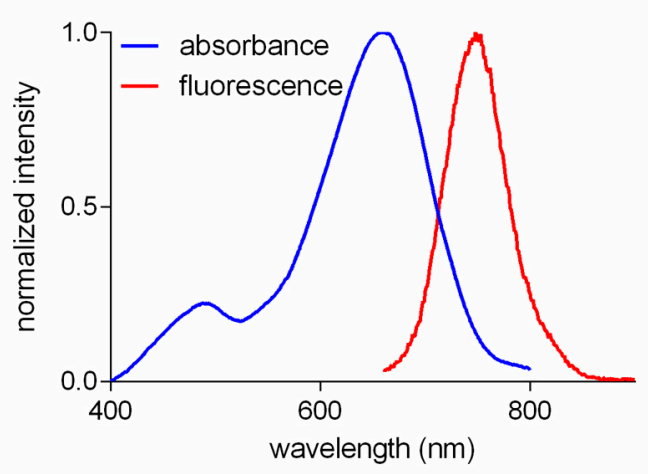

(D)

Figure 2. Normalized absorbance and fluorescence of compounds $1 \mathbf{a}-\mathbf{d}\left(6 \mu \mathrm{M}, 37^{\circ} \mathrm{C}\right)$ in $\mathrm{pH} 7.24$ $10 \mathrm{mM}$ PBS buffer. (A) compound 1a: $\lambda_{\max \text { abs }} 783 \mathrm{~nm}$ (blue), $\lambda_{\text {max emiss }} 809 \mathrm{~nm}$ (red). (B) compound 1b: $\lambda_{\text {max abs }} 766 \mathrm{~nm}$ (blue), $\lambda_{\text {max emiss }} 791 \mathrm{~nm}$ (red). (C) compound 1c: $\lambda_{\max }$ abs $578 \mathrm{~nm}$ (blue), $\lambda_{\max \text { emiss }}$ $648 \mathrm{~nm}$ (red). (D) compound 1d: $\lambda_{\max \text { abs }} 658 \mathrm{~nm}$ (blue), $\lambda_{\max \text { emiss }} 748 \mathrm{~nm}$ (red). 


\subsection{Meso-Cl Functionality of Cy-7 Dyes Is Essential for Cys-Selective Protein Labeling}

Vimentin, a structural protein, was chosen for study because it has only one Cys residue (C328). Vimentin $(1 \mu \mathrm{g}, 1 \mu \mathrm{M})$ was incubated with Cy-7 dyes containing meso-Cl (MHI-148, IR-780, IR-783, and DZ-1; $10 \mu \mathrm{M}$ ) and with Cy-7 dyes without meso-Cl (ICG and 1a) for comparison (throughout, $10 \mu \mathrm{M}$ in $50 \mathrm{mM} \mathrm{pH} 7.24$ HEPES buffer at $37^{\circ} \mathrm{C}$ for up to $24 \mathrm{~h}$ ). An equal amount of the samples (100 ng) was electrophoresed under reducing conditions, and the gel was analyzed using an NIR imager. Only the $\mathrm{Cy}-7$ dyes containing meso- $\mathrm{Cl}$ reacted to give a band observable at $800 \mathrm{~nm}$ (Figure 3).

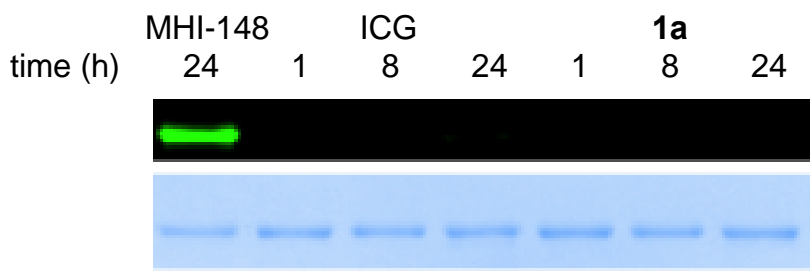

(A)

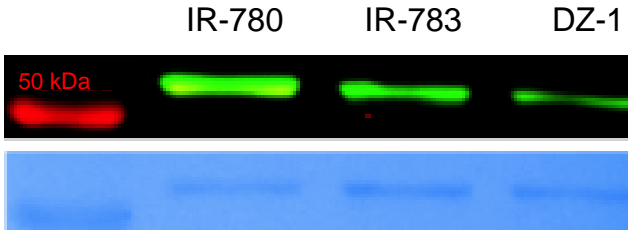

(B)

Figure 3. Near-infrared (NIR) fluorescent gel image of (A) vimentin $(1 \mu \mathrm{M})$ incubated with different cyanines $(10 \mu \mathrm{M})$ in $50 \mathrm{mM}$ pH 7.24 HEPES buffer at different incubation times; (B) vimentin $(1 \mu \mathrm{M})$ incubated with IR-780, IR-783, and DZ-1 in the same buffer as (A) for $24 \mathrm{~h}$. CBB-G250 staining indicated an equal amount of protein (100 $\mathrm{ng}$ ) was loaded into gel.

Further evidence for the superior reactivities of Cys side-chains over other nucleophilic amino acid residues was obtained via competition experiments. Thus, MHI-148 $(200 \mu \mathrm{M})$ in $50 \mathrm{mM} \mathrm{pH} 8.0$ HEPES buffer was incubated with equimolecular amounts of five amino acids (Scheme 2) at $37^{\circ} \mathrm{C}$, and the reaction was monitored by HPLC up to $27 \mathrm{~h}$. Prototypes of this experiment were intended to measure relative rates, however, only formation of the Cys-product 1a occurred (HPLC spike with the standard from Scheme 1 (Figure 4) and LC-MS analyses). Under these conditions, approximately $32 \%$ of MHI-148 was substituted and $68 \%$ remained after $15 \mathrm{~h}$. The reaction did not go to completion due to equilibrium of the reaction or due to oxidation of cysteines in aqueous conditions. This observation implied amine, alcohol, and phenol side-chains in the protein did not react with the dye.<smiles>CN(C)CCCCC(N)C(=O)O</smiles>

all equimolar<smiles>CC(=O)CN1C(=CC=C2CCCC(C=CC3=[N+](CCCC(=O)O)c4ccccc4C3(C)C)=C2Cl)C(C)(C)c2ccccc21</smiles>
$\underset{\mathrm{pH} 8,37^{\circ} \mathrm{C}, 27 \mathrm{~h}}{\stackrel{\text { HEPES, }}{\longrightarrow} \mathrm{mM}}$

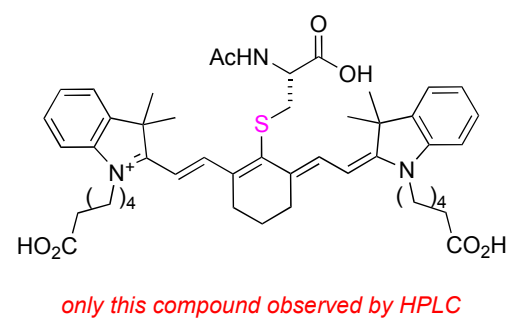

only this compound observed by HPLC

Scheme 2. Competition study of MHI-148 with amino acids in aqueous buffer.

Blocking experiments were performed to be absolutely sure that the vimentin Cys was the reactive group for coupling to MHI-148 in aqueous buffer at $37^{\circ} \mathrm{C}$. Thus, maleimide-blocked protein $[27,28]$ was formed by incubating vimentin with 6-maleimidohexanoic acid (6-MA; $18 \mathrm{~h}$ in $50 \mathrm{mM} \mathrm{pH} \mathrm{7.24}$ HEPES buffer at $37^{\circ} \mathrm{C}$ ). Vimentin and the thiol-blocked vimentin were incubated with MHI-148 for different incubation times, then analyzed using SDS-PAGE gel electrophoresis. Figure 4C shows that the concentration of MHI-148 covalently bound to vimentin progressively increased (NIR fluorescence at $\sim 800 \mathrm{~nm}$ ), whereas no fluorescent band was observed for the thiol-blocked vimentin. 


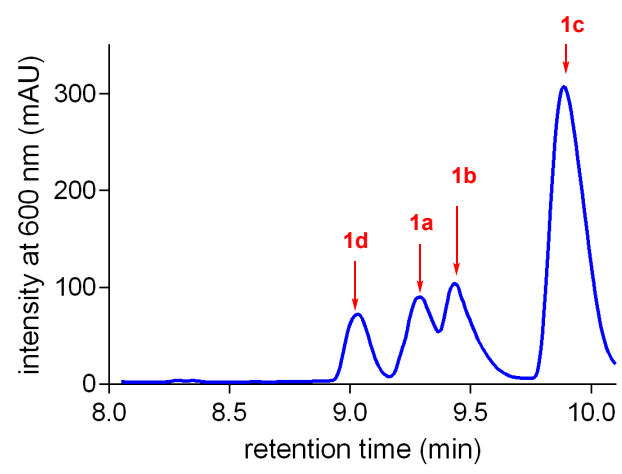

(A)

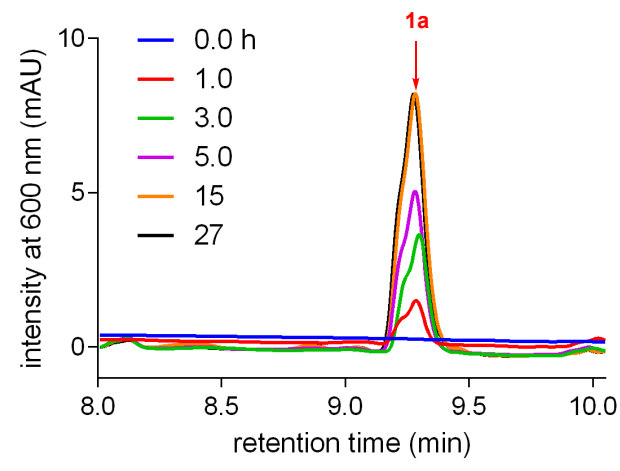

(B)

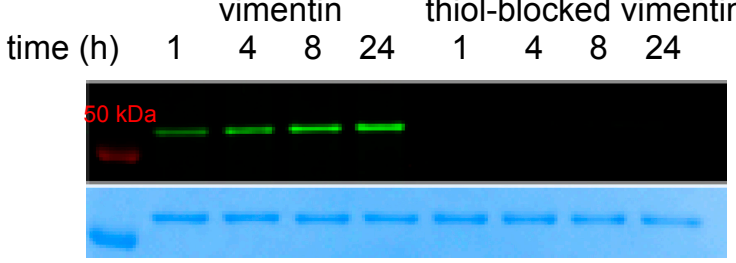

(C)

Figure 4. High-performance liquid chromatography (HPLC) analysis of (A) $200 \mu \mathrm{M}$ of each amino-acid-conjugate standard 1a-d in $50 \mathrm{mM}$ pH 8.0 HEPES buffer; (B) kinetic study for $200 \mu \mathrm{M}$ of MHI-148 with $200 \mu \mathrm{M}$ of each amino acid ( $N$-acetyl-L-Cys, $N$-acetyl-L-Tyr, $N \alpha$-acetyl-L-Lys, $N \varepsilon$-acetyl-L-Lys, and L-proline) in $50 \mathrm{mM} \mathrm{pH} 8.0$ HEPES buffer incubating at $37^{\circ} \mathrm{C}$; (C) NIR fluorescent gel image of vimentin or 6-MA-blocked vimentin $(1 \mu \mathrm{M})$ incubated with $\mathrm{MHI}-148(1 \mu \mathrm{M})$ in $50 \mathrm{mM} \mathrm{pH}$ 7.24 HEPES buffer at different incubation times.

Overall, based on all the experiments above, we concluded that MHI-148 selectively binds the only free Cys in vimentin, $\mathrm{C} 328$, in aqueous buffer at $37^{\circ} \mathrm{C}$, and went on to calibrate the efficiency of binding. Thus, NIR fluorescence $(>800 \mathrm{~nm})$ in gel electrophoresis was quantitative for vimentin $\left(1 \mu \mathrm{M}\right.$ in $50 \mathrm{mM}$ pH 7.24 HEPES buffer) when incubated with of MHI-148 $\left(0-30 \mu \mathrm{M}, 3 \mathrm{~h}\right.$ at $\left.37{ }^{\circ} \mathrm{C}\right)$. Fluorescence intensities of the salient band saturated at $10 \mu \mathrm{M}$ (Figure 5a), which means the tested fluorescent compound can quantitatively label the protein at a 10:1 ratio within $3 \mathrm{~h}$ when incubated under these conditions in HEPES aqueous buffer. Experiments to test sensitivity revealed labeled vimentin was detectable at concentrations as low as $1 \mathrm{ng}$ on our gel imaging apparatus (Figure 5b).

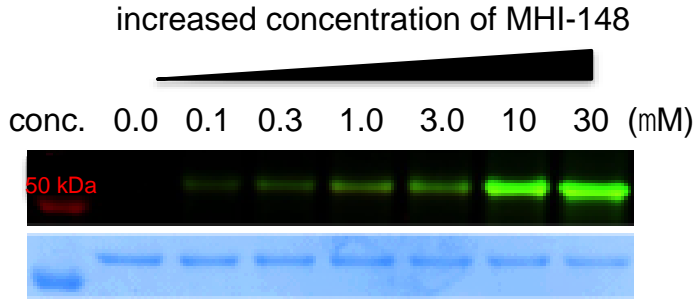

(A) decreased loading of MHI-148-vimentin

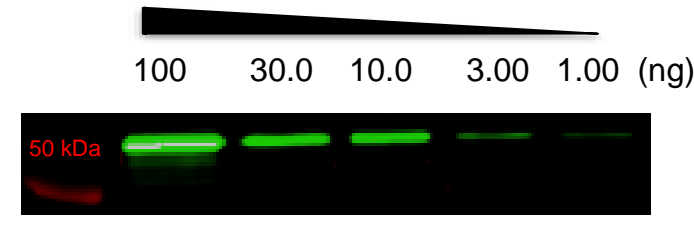

(B)

Figure 5. NIR fluorescent gel image of (A) vimentin $(1 \mu \mathrm{M})$ incubated with different concentrations of MHI-148 in $50 \mathrm{mM}$ pH 7.24 HEPES buffer for $3 \mathrm{~h}$ at $37{ }^{\circ} \mathrm{C}$ (B) 10:1 concentration ratio of MHI-148:vimentin sample was loaded into 10\% SDS-PAGE gel with different amounts of vimentin sample.

\subsection{Labeling of Other Proteins Using MHI-148}

Several proteins with and without free Cys residues were labeled to test the robustness of the method developed for vimentin. NEDD8-activating enzyme (NAE) [29], Ubc12 [30], and PCSK9 [31] contain free thiols (reduced Cys residues), whereas NEDD8 [29] (no Cys in sequences), truncated suPAR 
(residues 1-281, 12 disulfides) [32], and EGFR (25 disulfides) [33] have none. Figure 6 shows that only the proteins containing sulfhydryl groups reacted under the standard conditions. NAE consists of two subunits (APPBP1 and UBA3) which each contain free Cys; hence, two NIR fluorescence bands were observed for that sample.

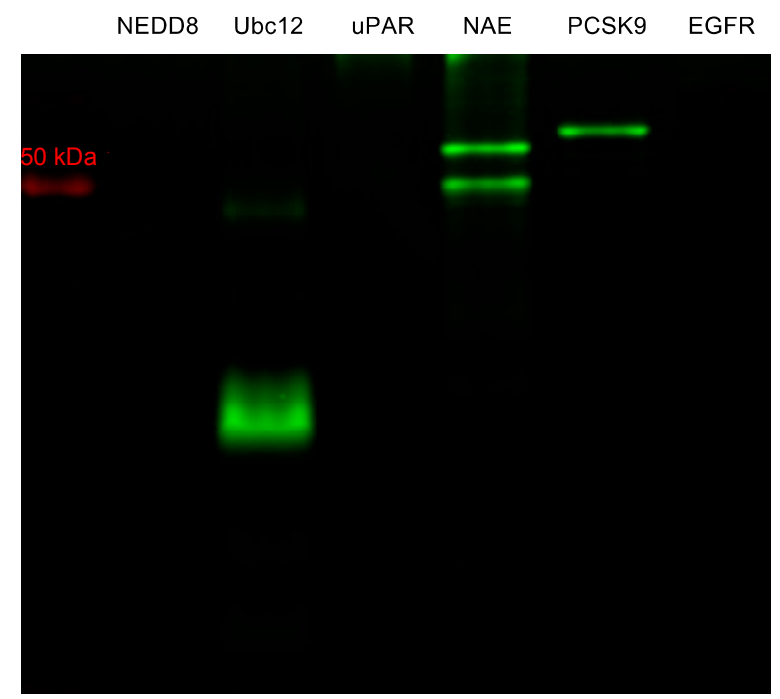

Figure 6. NIR fluorescent gel image of diverse proteins $(4 \mu \mathrm{M})$ incubated with MHI-148 $(4 \mu \mathrm{M})$ for $3 \mathrm{~h}$ using $50 \mathrm{mM}$ pH $7.24 \mathrm{HEPES}$ buffer at $37^{\circ} \mathrm{C}$.

\section{Materials and Methods}

\subsection{General Information}

All reactions were carried out with dry solvents under anhydrous conditions under an inert atmosphere (argon). Glassware was dried in an oven at $140{ }^{\circ} \mathrm{C}$ for a minimum of $6 \mathrm{~h}$ prior to use for all reactions. IR-783 and IR-780 were purchased from Sigma Aldrich (Atlanta, GA, USA) and abcr GmBH (Karlsruhe, Germany), respectively, and DZ-1 and MHI-148 were synthesized according to literature protocol $[7,12,14,34]$. All other reagents were purchased at a high commercial quality (typically $97 \%$ or higher) and used without further purification, unless otherwise stated. Products were purified using a reverse-phase column on a preparative high-performance liquid chromatography (prep HPLC) (Agilent, Santa Clara, CA, USA) obtained from solid-phase synthesis in 10\%-95\% MeCN/water with $0.05 \%$ trifluoroacetic acid over $20 \mathrm{~min}$. High-field NMR spectra were recorded with Bruker Avance III (Billerica, MA, USA) at $400 \mathrm{MHz}$ for ${ }^{1} \mathrm{H}$, and $100 \mathrm{MHz}$ for ${ }^{13} \mathrm{C}$ for all compounds. All spectra were calibrated using residual nondeuterated solvent as an internal reference (MeOD- $d_{4}:{ }^{1} \mathrm{H}-\mathrm{NMR}=3.30$, ${ }^{13} \mathrm{C}-\mathrm{NMR}=49.0$, DMSO- $\left.d_{6}:{ }^{1} \mathrm{H}-\mathrm{NMR}=2.50,{ }^{13} \mathrm{C}-\mathrm{NMR}=39.5\right)$. The following abbreviations were used to explain the multiplicities: $\mathrm{s}=$ singlet, $\mathrm{d}=$ doublet, $\mathrm{t}=$ triplet, $\mathrm{q}=$ quartet, quint = quintet, $\mathrm{dd}=\mathrm{double}$ doublet, $\mathrm{dt}=$ double triplet, $\mathrm{dq}=$ double quartet, and $\mathrm{m}=$ multiplet. Electrospray ionization mass spectrometry (ESI-MS) data were collected on a triple-stage quadrupole instrument (Thermo Scientific, Waltham, MA, USA) in a positive mode. All statistical analyses were carried out by GraphPad Prism version 6.0 (GraphPad Software, La Jolla, CA, USA).

\subsection{Synthesis and Characterization}

2-((E.)-2-((E)-2-(((R)-2-acetamido-2-carboxyethyl)thio)-3-(2-((E)-1-(5-carboxypentyl)-3,3-

dimethylindolin-2-ylidene)ethylidene)cyclohex-1-en-1-yl)vinyl)-1-(5-carboxypentyl)-3,3-dimethyl3H-indol-1-ium (1a)

To a solution of MHI-148 (25.0 mg, $0.04 \mathrm{mmol})$ in DMF (1.00 mL), N-acetyl-L-cysteine $(5.98 \mathrm{mg}$, $0.04 \mathrm{mmol})$ and ${ }^{\mathrm{i}} \mathrm{Pr}_{2} \mathrm{NEt}(9.41 \mu \mathrm{L}, 0.06 \mathrm{mmol})$ were added and the reaction was stirred at $25^{\circ} \mathrm{C}$ for 
$1 \mathrm{~h}$. Solvent was removed under a stream of nitrogen gas and purified by preparative reversed-phase HPLC (10\%-95\% $\mathrm{CH}_{3} \mathrm{CN} /$ water containing 0.05\% TFA). Compound was lyophilized to obtain green solid (23.4 mg, 78\%). ${ }^{1} \mathrm{H}-\mathrm{NMR}(400 \mathrm{MHz}, \mathrm{MeOD}) \delta 8.77(\mathrm{~d}, J=13.9 \mathrm{~Hz}, 2 \mathrm{H}), 7.49(\mathrm{~d}, J=7.3 \mathrm{~Hz}, 2 \mathrm{H})$, $7.45-7.36(\mathrm{~m}, 2 \mathrm{H}), 7.27(\mathrm{dd}, J=14.9,7.6 \mathrm{~Hz}, 4 \mathrm{H}), 6.28(\mathrm{~d}, J=13.8 \mathrm{~Hz}, 2 \mathrm{H}), 4.55(\mathrm{dd}, J=7.5,5.3 \mathrm{~Hz}, 1 \mathrm{H})$, $4.15(\mathrm{t}, J=6.9 \mathrm{~Hz}, 4 \mathrm{H}), 3.40(\mathrm{dd}, J=13.4,5.3 \mathrm{~Hz}, 1 \mathrm{H}), 3.12(\mathrm{dd}, J=13.4,7.5 \mathrm{~Hz}, 1 \mathrm{H}), 2.75-2.54(\mathrm{~m}, 4 \mathrm{H})$, $2.31(\mathrm{t}, J=7.3 \mathrm{~Hz}, 4 \mathrm{H}), 1.98-1.92(\mathrm{~m}, 2 \mathrm{H}), 1.95(\mathrm{~s}, 3 \mathrm{H}), 1.90-1.80(\mathrm{~m}, 4 \mathrm{H}), 1.74(\mathrm{~s}, 12 \mathrm{H}), 1.72-1.64(\mathrm{~m}, 4 \mathrm{H})$, 1.55-1.45 (m, 4H). ${ }^{13} \mathrm{C}-\mathrm{NMR}(100 \mathrm{MHz}, \mathrm{MeOD}) \delta 177.23,173.86,173.21,172.93,157.83,146.46,143.72$, $142.48,134.54,129.83,126.27,123.46,112.00,102.20,54.36,50.51,50.49,49.85,44.97,39.51,34.61,28.44$, 28.02, 27.38, 25.65, 22.75, 22.03. HRMS calculated for $\mathrm{C}_{47} \mathrm{H}_{60} \mathrm{~N}_{3} \mathrm{O}_{7} \mathrm{~S}^{+}(\mathrm{M})^{+}$: 810.4146; found 810.4166.

6-((E.)-2-((E)-2-(2-(4-(2-acetamido-2-carboxyethyl)phenoxy)-3-((E)-2-(1-(5-carboxypentyl)-3,3dimethyl-3H-indol-1-ium-2-yl)vinyl)cyclohex-2-en-1-ylidene)ethylidene)-3,3-dimethylindolin-1yl)hexanoate (1b)

$\mathrm{NaH}(0.89 \mathrm{mg}, 0.04 \mathrm{mmol})$ was added to a solution of $\mathrm{N}$-acetyl-L-tyrosine $(8.25 \mathrm{mg}, 0.04 \mathrm{mmol})$ in DMF $(1.00 \mathrm{~mL})$ and the reaction was stirred at $25^{\circ} \mathrm{C}$ for $30 \mathrm{~min}$. MHI-148 $(25.0 \mathrm{mg}, 0.04 \mathrm{mmol})$ was then added to the above reaction and the reaction was stirred for an additional $18 \mathrm{~h}$ at $25^{\circ} \mathrm{C}$. Solvent was removed under a stream of nitrogen gas and purified by preparative reversed-phase HPLC (10\%-95\% $\mathrm{CH}_{3} \mathrm{CN} /$ water containing $0.05 \%$ TFA). Compound was lyophilized to obtain green solid (12.2 mg, 38\%). ${ }^{1} \mathrm{H}-\mathrm{NMR}(400 \mathrm{MHz}, \mathrm{MeOD}) \delta 8.01-7.92(\mathrm{~m}, 2 \mathrm{H}), 7.36(\mathrm{t}, J=7.8 \mathrm{~Hz}, 4 \mathrm{H}), 7.31-7.15(\mathrm{~m}$, $6 \mathrm{H}), 7.05(\mathrm{~d}, J=8.7 \mathrm{~Hz}, 2 \mathrm{H}), 6.13(\mathrm{~d}, J=14.2 \mathrm{~Hz}, 2 \mathrm{H}), 4.54(\mathrm{dd}, J=9.1,5.2 \mathrm{~Hz}, 1 \mathrm{H}), 4.09(\mathrm{t}, J=7.3 \mathrm{~Hz}$, $4 \mathrm{H}), 3.14(\mathrm{dd}, J=14.0,5.2 \mathrm{~Hz}, 1 \mathrm{H}), 2.84(\mathrm{dd}, J=14.2,9.2 \mathrm{~Hz}, 1 \mathrm{H}), 2.73(\mathrm{t}, J=5.8 \mathrm{~Hz}, 4 \mathrm{H}), 2.30(\mathrm{t}$, $J=7.3 \mathrm{~Hz}, 4 \mathrm{H}), 2.04(\mathrm{t}, J=7.3 \mathrm{~Hz}, 2 \mathrm{H}), 1.84(\mathrm{~s}, 3 \mathrm{H}), 1.83-1.73(\mathrm{~m}, 4 \mathrm{H}), 1.67(\mathrm{dd}, J=15.1,7.5 \mathrm{~Hz}, 4 \mathrm{H})$, $1.46(\mathrm{t}, J=7.7 \mathrm{~Hz}, 4 \mathrm{H}), 1.33(\mathrm{~s}, 12 \mathrm{H}) .{ }^{13} \mathrm{C}-\mathrm{NMR}(100 \mathrm{MHz}, \mathrm{MeOD}) \delta 177.20,174.59,173.75,173.05$, $165.43,160.25,143.57,143.34,142.51,132.96,132.16,129.76,126.19,123.40,123.20,115.75,111.94,100.93$, $55.48,50.27,44.85,37.62,34.59,28.25,27.96,27.33,25.63,25.21,22.48,22.39$. HRMS calculated for $\mathrm{C}_{53} \mathrm{H}_{64} \mathrm{~N}_{3} \mathrm{O}_{8}{ }^{+}(\mathrm{M})^{+}$: 870.4688; found 870.4675 .

1-(5-C.arboxypentyl)-2-((E)-2-((E)-3-(2-((E)-1-(5-carboxypentyl)-3,3-dimethylindolin-2-ylidene) ethylidene)-2-((S)-2-carboxypyrrolidin-1-yl)cyclohex-1-en-1-yl)vinyl)-3,3-dimethyl-3H-indol-1ium (1c)

To a solution of MHI-148 $(25.0 \mathrm{mg}, 0.04 \mathrm{mmol})$ in DMF $(1.00 \mathrm{~mL})$, L-proline $(4.26 \mathrm{mg}, 0.04 \mathrm{mmol})$ and ${ }^{i} \operatorname{Pr}_{2} \mathrm{NEt}(6.27 \mu \mathrm{L}, 0.04 \mathrm{mmol})$ were added and the reaction was stirred at $60{ }^{\circ} \mathrm{C}$ monitored by Agilent LC-MS. The reaction reached equilibrium after $2 \mathrm{~h}$ and the solvent was removed under a stream of nitrogen gas and purified by preparative reversed-phase HPLC $\left(10 \%-95 \% \mathrm{CH}_{3} \mathrm{CN} /\right.$ water containing $0.05 \%$ TFA). Compound was lyophilized to obtain blue solid (5.18 mg, 18\%). ${ }^{1} \mathrm{H}-\mathrm{NMR}(400 \mathrm{MHz}$, DMSO) $\delta 7.42(\mathrm{~d}, J=7.3 \mathrm{~Hz}, 2 \mathrm{H}), 7.28(\mathrm{t}, J=7.7 \mathrm{~Hz}, 2 \mathrm{H}), 7.11(\mathrm{~d}, J=7.7 \mathrm{~Hz}, 2 \mathrm{H}), 7.04(\mathrm{t}, J=7.2 \mathrm{~Hz}, 2 \mathrm{H})$, $5.68(\mathrm{~d}, J=12.4 \mathrm{~Hz}, 2 \mathrm{H}), 4.96(\mathrm{~d}, J=7.3 \mathrm{~Hz}, 2 \mathrm{H}), 4.02-3.97(\mathrm{~m}, 1 \mathrm{H}), 3.90-3.87(\mathrm{~m}, 4 \mathrm{H}), 2.76-2.57(\mathrm{~m}, 3 \mathrm{H})$, 2.46-2.29 (m, 3H), 2.28-2.18 (m, 1H), $2.20(\mathrm{t}, J=7.3 \mathrm{~Hz}, 4 \mathrm{H}), 2.09-1.98(\mathrm{~m}, 3 \mathrm{H}), 1.79-1.70(\mathrm{~m}, 2 \mathrm{H})$, 1.70-1.62 (m, 4H), $1.57(\mathrm{~s}, 6 \mathrm{H}), 1.61-1.48(\mathrm{~m}, 4 \mathrm{H}), 1.54(\mathrm{~s}, 6 \mathrm{H}), 1.45-1.30(\mathrm{~m}, 4 \mathrm{H}) .{ }^{13} \mathrm{C}-\mathrm{NMR}(100 \mathrm{MHz}$, DMSO) $\delta 174.29,172.71,166.02,158.00,142.99,139.74,136.52,128.11,123.13,122.28,122.00,109.00,94.22$, $64.69,56.49,46.93,42.26,33.52,30.04,29.59,28.65,28.11,26.70,25.81,24.22,20.65$. HRMS calculated for $\mathrm{C}_{47} \mathrm{H}_{60} \mathrm{~N}_{3} \mathrm{O}_{6}{ }^{+}(\mathrm{M})^{+}$: 762.4477; found 762.4457.

2-((E.)-2-((E)-2-(((S)-5-acetamido-1-carboxypentyl)amino)-3-(2-((E)-1-(5-carboxypentyl)-3,3dimethylindolin-2-ylidene)ethylidene)cyclohex-1-en-1-yl)vinyl)-1-(5-carboxypentyl)-3,3-dimethyl3 H-indol-1-ium (1d)

To a solution of MHI-148 (25.0 mg, $0.04 \mathrm{mmol})$ in DMF/ $\mathrm{H}_{2} \mathrm{O}(1: 1 ; 1.00 \mathrm{~mL}), N \varepsilon$-acetyl-L-lysine $(6.96 \mathrm{mg}, 0.04 \mathrm{mmol})$ and ${ }^{\mathrm{i}} \mathrm{Pr}_{2} \mathrm{NEt}(6.27 \mu \mathrm{L}, 0.04 \mathrm{mmol})$ were added and the reaction was stirred at $60{ }^{\circ} \mathrm{C}$ monitored by Agilent LC-MS. The reaction reached equilibrium after $20 \mathrm{~h}$ and the solvent was removed under a stream of nitrogen gas and purified by preparative reversed-phase HPLC $(10 \%-95 \%$ $\mathrm{CH}_{3} \mathrm{CN} /$ water containing $0.05 \%$ TFA). Compound was lyophilized to obtain blue solid (4.33 mg, $18 \%$ ). 
${ }^{1} \mathrm{H}-\mathrm{NMR}(400 \mathrm{MHz}, \mathrm{DMSO}) \delta 8.02(\mathrm{~d}, J=9.4 \mathrm{~Hz}, 1 \mathrm{H}), 7.78(\mathrm{~d}, J=12.9 \mathrm{~Hz}, 2 \mathrm{H}), 7.45(\mathrm{~d}, J=7.2 \mathrm{~Hz}$, 2H), 7.35-7.28 (m, 2H), $7.24(\mathrm{dd}, J=11.6,3.9 \mathrm{~Hz}, 1 \mathrm{H}), 7.17(\mathrm{~d}, J=8.0 \mathrm{~Hz}, 2 \mathrm{H}), 7.09(\mathrm{t}, J=7.4 \mathrm{~Hz}, 2 \mathrm{H})$, $7.05-7.00(\mathrm{~m}, 1 \mathrm{H}), 5.85(\mathrm{~d}, J=13.2 \mathrm{~Hz}, 2 \mathrm{H}), 4.43(\mathrm{dd}, J=13.9,8.8 \mathrm{~Hz}, 1 \mathrm{H}), 4.00-3.95(\mathrm{~m}, 4 \mathrm{jH}), 3.68-3.61$ $(\mathrm{m}, 4 \mathrm{H}), 3.01(\mathrm{t}, J=5.4 \mathrm{~Hz}, 2 \mathrm{H}), 2.56(\mathrm{dd}, J=13.9,7.2 \mathrm{~Hz}, 2 \mathrm{H}), 2.42-2.33(\mathrm{~m}, 2 \mathrm{H}), 2.20(\mathrm{dd}, J=13.4$, $6.3 \mathrm{~Hz}, 4 \mathrm{H}), 1.75(\mathrm{~s}, 3 \mathrm{H}), 1.72-1.63(\mathrm{~m}, 6 \mathrm{H}), 1.60(\mathrm{~s}, 12 \mathrm{H}), 1.52(\mathrm{dd}, J=14.8,7.4 \mathrm{~Hz}, 6 \mathrm{H}), 1.43-1.34$ $(\mathrm{m}, 8 \mathrm{H}) .{ }^{13} \mathrm{C}-\mathrm{NMR}(100 \mathrm{MHz}$, DMSO) $\delta 174.22,173.25,168.88,167.91,142.71,140.05,128.12,127.58$, $122.74,122.42,121.96,120.58,109.39,108.49,95.36,47.32,43.24,42.35,38.21,33.47,28.99,28.01,27.60$, 25.94, 25.77, 25.62, 24.45, 24.18, 24.11, 24.05, 22.53. HRMS calculated for $\mathrm{C}_{50} \mathrm{H}_{67} \mathrm{~N}_{4} \mathrm{O}_{7}^{+}(\mathrm{M})^{+}$: 835.5004; found 835.4972 .

\subsection{UV-Vis and Fluorescence Analysis}

Here, $6 \mu \mathrm{M}$ of compounds 1a-d samples in $10 \mathrm{mM}$ PBS buffer was prepared by diluting their corresponding stock solution $(20 \mathrm{mM})$ in DMSO using pH $7.2410 \mathrm{mM}$ PBS buffer. The absorbance and fluorescence of these samples were analyzed using a Varian Cary 100 UV-Vis spectrometer and Varian Cary Eclipse fluorescence spectrophotometer, respectively. The excitation wavelength for compounds 1a-d was set as 740, 720, 580, and $650 \mathrm{~nm}$, respectively. The normalized absorbance and fluorescence data were plotted using GraphPad Prism version 6.0 (GraphPad Software).

\subsection{NIR Gel Image Protocol}

Different cyanines $(10 \mu \mathrm{M} ; 20 \mathrm{mM}$ stock in DMSO) were incubated with vimentin $(1 \mu \mathrm{M} ; 1 \mu \mathrm{g})$ in $\mathrm{pH}$ 7.24 HEPES buffer $(50 \mathrm{mM})$ at $37^{\circ} \mathrm{C}$ monitored up to $24 \mathrm{~h}$. For this, $100 \mathrm{ng}$ of each cyanine-vimentin conjugate samples was treated under reducing condition with heating at $95^{\circ} \mathrm{C}$ for $10 \mathrm{~min}$ and loaded into $15 \%$ SDS-PAGE for electrophoresis. The gel was washed with deionized water (10 $\mathrm{min} \times 3$ times), and the gel was analyzed by an Odyssey imager to detect the NIR fluorescence.

\subsection{Preparation of Thiol-Blocked Vimentin}

Using $\mathrm{pH}$ 7.24 HEPES buffer $(50 \mathrm{mM})$, thiol-blocked vimentin was prepared by incubating 6-maleimide-hexanoic acid $(6-\mathrm{MA}, 10 \mu \mathrm{M})$ with vimentin $(1 \mu \mathrm{g}, 1 \mu \mathrm{M})$ for $18 \mathrm{~h}$ at $37{ }^{\circ} \mathrm{C}$. The thiol-blocked vimentin solution was directly used to incubate with MHI-148 $(1 \mu \mathrm{M})$ without further purifications.

\subsection{Kinetic Study of MHI-148 with Amino Acids in Aqueous Buffer}

To a solution of MHI-148 $(400 \mu \mathrm{M})$ in pH 8.00 HEPES buffer $(500 \mu \mathrm{L}), 100 \mu \mathrm{L}$ of each amino acid solution $(2.00 \mathrm{mM})$ in $\mathrm{pH} 8.00$ HEPES buffer was added to make a final concentration of $200 \mu \mathrm{M}$ of each reagent. The reaction was incubated and shaken at $37^{\circ} \mathrm{C}$ and was monitored using HPLC at $600 \mathrm{~nm}$ from 0 to $27 \mathrm{~h}$ to reach reaction equilibrium. The data was plotted using GraphPad Prism version 6.0 (GraphPad Software).

\subsection{NIR Gel Image of MHI-148 with Different Proteins}

Different proteins, including NEDD8, Ubc12, truncated suPAR (residues 1-281), NAE, PCSK9, and EGFR $(4 \mu \mathrm{M} ; 1 \mu \mathrm{g})$, were incubated with MHI-148 $(4 \mu \mathrm{M})$ in pH 7.24 HEPES buffer $(50 \mathrm{mM})$ at $37^{\circ} \mathrm{C}$ for $3 \mathrm{~h}$. For this, $500 \mathrm{ng}$ of each protein samples were treated under nonreducing condition with heating at $95^{\circ} \mathrm{C}$ for $10 \mathrm{~min}$ and loaded into $10 \%$ SDS-PAGE for electrophoresis. The gel was washed with deionized water (10 $\mathrm{min} \times 3$ times), and the gel was analyzed by an Odyssey imager to detect the NIR fluorescence.

\section{Conclusions}

MHI-148 can label proteins that have free Cys residues such as serum albumin [35] and vimentin. Other $\mathrm{Cy}-7$ dyes containing meso- $\mathrm{Cl}$ were only used to label vimentin in this work, but it would 
be unsurprising if they can be used. It seems clear that this methodology could be applied with a high probability of success to conveniently conjugate meso-Cl NIR dyes to antibodies, monobodies, and nanobodies to form selective agents for optical imaging in vivo. Traditional conjugation techniques tend to require modification of the dye to include maleimide or succinimide functionality $[28,36,37]$, but the method developed here circumvents that process.

Supplementary Materials: The NMR and mass spectrometry of compounds 1a-d and picture of Coomassie blue staining for SDS-PAGE are available online.

Author Contributions: C.-M.L. designed the research. C.-M.L. and S.M.U. carried out the experiments and analyzed the data. All authors contributed to write the manuscript.

Funding: Financial support was provided by a DoD BCRP Breakthrough Award [BC141561], CPRIT [RP150559 and RP170144], The Robert A. Welch Foundation [A-1121], Texas A\&M University [RP180875], and The National Science Foundation [M1603497]. The NMR instrumentation of Texas A\&M University was supported by a grant from the National Science Foundation [DBI-9970232] and the Texas A\&M University system.

Acknowledgments: We would like to thank Raquel Sitcheran's laboratory at Texas A\&M University for the use of the Odyssey CLx NIR imager. The use of chemistry Mass Spectrometry Facility at Texas A\&M University is acknowledged.

Conflicts of Interest: The authors declare no conflict of interest.

\section{References}

1. Shi, C.; Wu Jason, B.; Pan, D. Review on near-infrared heptamethine cyanine dyes as theranostic agents for tumor imaging, targeting, and photodynamic therapy. J. Biomed. Opt. 2016, 21, 50901. [CrossRef] [PubMed]

2. Schaafsma, B.E.; Mieog, J.S.D.; Hutteman, M.; van der Vorst, J.R.; Kuppen, P.J.K.; Loewik, C.W.G.M.; Frangioni, J.V.; van de Velde, C.J.H.; Vahrmeijer, A.L. The clinical use of indocyanine green as a near-infrared fluorescent contrast agent for image-guided oncologic surgery. J. Surg. Oncol. 2011, 104, 323-332. [CrossRef] [PubMed]

3. Alander, J.T.; Kaartinen, I.; Laakso, A.; Patila, T.; Spillmann, T.; Tuchin, V.V.; Venermo, M.; Valisuo, P. A review of indocyanine green fluorescent imaging in surgery. Int. J. Biomed. Imaging 2012, 2012. [CrossRef] [PubMed]

4. Nagahara, R.; Onda, N.; Yamashita, S.; Kojima, M.; Inohana, M.; Eguchi, A.; Nakamura, M.; Matsumoto, S.; Yoshida, T.; Shibutani, M. Fluorescence tumor imaging by i.v. administered indocyanine green in a mouse model of colitis-associated colon cancer. Cancer Sci. 2018, 109, 1638-1647. [CrossRef] [PubMed]

5. Luo, S.; Zhang, E.; Su, Y.; Cheng, T.; Shi, C. A review of NIR dyes in cancer targeting and imaging. Biomaterials 2011, 32, 7127-7138. [CrossRef] [PubMed]

6. James, N.S.; Chen, Y.; Joshi, P.; Ohulchanskyy, T.Y.; Ethirajan, M.; Henary, M.; Strekowski, L.; Pandey, R.K. Evaluation of polymethine dyes as potential probes for near infrared fluorescence imaging of tumors: Part-1. Theranostics 2013, 3, 692-702. [CrossRef] [PubMed]

7. Yang, X.; Shi, C.; Tong, R.; Qian, W.; Zhau, H.E.; Wang, R.; Zhu, G.; Cheng, J.; Yang, V.W.; Cheng, T.; et al. Near IR heptamethine cyanine dye-mediated cancer imaging. Clin. Cancer Res. 2010, 16, 2833-2844. [CrossRef] [PubMed]

8. Henary, M.; Pannu, V.; Owens, E.A.; Aneja, R. Near infrared active heptacyanine dyes with unique cancer-imaging and cytotoxic properties. Bioorg. Med. Chem. Lett. 2012, 22, 1242-1246. [CrossRef] [PubMed]

9. Yuan, J.; Yi, X.; Yan, F.; Wang, F.; Qin, W.; Wu, G.; Yang, X.; Shao, C.; Chung, L.W.K. Near-infrared fluorescence imaging of prostate cancer using heptamethine carbocyanine dyes. Mol. Med. Rep. 2015, 11, 821-828. [CrossRef] [PubMed]

10. Zhao, N.; Zhang, C.; Zhao, Y.; Bai, B.; An, J.; Zhang, H.; Shi, C.; Wu Jason, B. Optical imaging of gastric cancer with near-infrared heptamethine carbocyanine fluorescence dyes. Oncotarget 2016, 7, 57277-57289. [CrossRef] [PubMed]

11. Yang, X.; Shao, C.; Wang, R.; Chu, C.-Y.; Hu, P.; Master, V.; Osunkoya, A.O.; Kim, H.L.; Zhau, H.E.; Chung, L.W.K. Optical imaging of kidney cancer with novel near infrared heptamethine carbocyanine fluorescent dyes. J. Urol. 2013, 189, 702-710. [CrossRef] [PubMed] 
12. Zhang, C.; Zhao, Y.; Zhang, H.; Chen, X.; Zhao, N.; Tan, D.; Zhang, H.; Shi, C. The application of heptamethine cyanine Dye DZ-1 and indocyanine green for imaging and targeting in xenograft models of hepatocellular carcinoma. Int. J. Mol. Sci. 2017, 18, 1332. [CrossRef] [PubMed]

13. Wu, J.B.; Lin, T.-P.; Gallagher, J.D.; Kushal, S.; Chung, L.W.K.; Zhau, H.E.; Olenyuk, B.Z.; Shih, J.C. Monoamine oxidase a inhibitor-near-infrared dye conjugate reduces prostate tumor growth. J. Am. Chem. Soc. 2015, 137, 2366-2374. [CrossRef] [PubMed]

14. Wu, J.B.; Shi, C.; Chu, G.C.-Y.; Xu, Q.; Zhang, Y.; Li, Q.; Yu, J.S.; Zhau, H.E.; Chung, L.W.K. Near-infrared fluorescence heptamethine carbocyanine dyes mediate imaging and targeted drug delivery for human brain tumor. Biomaterials 2015, 67,1-10. [CrossRef] [PubMed]

15. Guan, Y.; Zhang, Y.; Xiao, L.; Li, J.; Wang, J.-P.; Chordia, M.D.; Liu, Z.-Q.; Chung, L.W.K.; Yue, W.; Pan, D. Improving therapeutic potential of farnesylthiosalicylic acid: Tumor specific delivery via conjugation with heptamethine cyanine dye. Mol. Pharm. 2017, 14, 1-13. [CrossRef] [PubMed]

16. Lv, Q.; Yang, X.; Wang, M.; Yang, J.; Qin, Z.; Kan, Q.; Zhang, H.; Wang, Y.; Wang, D.; He, Z. Mitochondria-targeted prostate cancer therapy using a near-infrared fluorescence dye-monoamine oxidase A inhibitor conjugate. J. Control. Release 2018, 279, 234-242. [CrossRef] [PubMed]

17. Strekowski, L.; Lipowska, M.; Patonay, G. Facile derivatizations of heptamethine cyanine dyes. Synth. Commun. 1992, 22, 2593-2598. [CrossRef]

18. Strekowski, L.; Lipowska, M.; Patonay, G. Substitution reactions of a nucleofugal group in heptamethine cyanine dyes. Synthesis of an isothiocyanato derivative for labeling of proteins with a near-infrared chromophore. J. Org. Chem. 1992, 57, 4578-4580. [CrossRef]

19. Cha, J.; Nani, R.R.; Luciano, M.P.; Broch, A.; Kim, K.; Namgoong, J.-M.; Kulkarni, R.A.; Meier, J.L.; Kim, P.; Schnermann, M.J. A chemically stable fluorescent marker of the ureter. Bioorg. Med. Chem. Lett. 2018, 28, 2741-2745. [CrossRef] [PubMed]

20. Nani, R.R.; Shaum, J.B.; Gorka, A.P.; Schnermann, M.J. Electrophile-integrating smiles rearrangement provides previously inaccessible C4'-O-alkyl heptamethine cyanine fluorophores. Org. Lett. 2015, 17, 302-305. [CrossRef] [PubMed]

21. Samanta, A.; Vendrell, M.; Das, R.; Chang, Y.T. Development of photostable near-infrared cyanine dyes. Chem. Commun. (Camb) 2010, 46, 7406-7408. [CrossRef] [PubMed]

22. Das, R.K.; Samanta, A.; Ha, H.H.; Chang, Y.T. Solid phase synthesis of ultra-photostable cyanine NIR dye library. RSC Adv. 2011, 1, 573-575. [CrossRef]

23. Pascal, S.; Haefele, A.; Monnereau, C.; Charaf-Eddin, A.; Jacquemin, D.; Le Guennic, B.; Andraud, C.; Maury, O. Expanding the polymethine paradigm: Evidence for the contribution of a bis-dipolar electronic structure. J. Phys. Chem. A 2014, 118, 4038-4047. [CrossRef] [PubMed]

24. Guo, Z.; Zhu, W.; Zhu, M.; Wu, X.; Tian, H. Near-infrared cell-permeable $\mathrm{Hg}^{+}{ }^{+}$-selective ratiometric fluorescent chemodosimeters and fast indicator paper for $\mathrm{MeHg}^{+}$based on tricarbocyanines. Chem. Eur. J. 2010, 16, 14424-14432. [CrossRef] [PubMed]

25. Njiojob, C.N.; Owens, E.A.; Narayana, L.; Hyun, H.; Choi, H.S.; Henary, M. Tailored near-infrared contrast agents for image guided surgery. J. Med. Chem. 2015, 58, 2845-2854. [CrossRef] [PubMed]

26. Peng, X.; Song, F.; Lu, E.; Wang, Y.; Zhou, W.; Fan, J.; Gao, Y. Heptamethine cyanine dyes with a large Stokes shift and strong fluorescence: A paradigm for excited-state intramolecular charge transfer. J. Am. Chem. Soc. 2005, 127, 4170-4171. [CrossRef] [PubMed]

27. Warnecke, A.; Fichtner, I.; Garmann, D.; Jaehde, U.; Kratz, F. Synthesis and biological activity of water-soluble maleimide derivatives of the anticancer drug carboplatin designed as albumin-binding prodrugs. Bioconjugate Chem. 2004, 15, 1349-1359. [CrossRef] [PubMed]

28. Nanda, J.S.; Lorsch, J.R. Labeling of a protein with fluorophores using maleimide derivitization. In Methods Enzymol; Lorsch, J.R., Ed.; Elsevier: San Diego, CA, USA, 2014; Volume 536, pp. 79-86.

29. Walden, H.; Podgorski, M.S.; Huang, D.T.; Miller, D.W.; Howard, R.J.; Minor, D.L., Jr.; Holton, J.M.; Schulman, B.A. The structure of the APPBP1-UBA3-NEDD8-ATP complex reveals the basis for selective ubiquitin-like protein activation by an E1. Mol. Cell 2003, 12, 1427-1437. [CrossRef]

30. Huang, D.T.; Miller, D.W.; Mathew, R.; Cassell, R.; Holton, J.M.; Roussel, M.F.; Schulman, B.A. A unique E1-E2 interaction required for optimal conjugation of the ubiquitin-like protein NEDD8. Nat. Struct. Mol. Biol. 2004, 11, 927-935. [CrossRef] [PubMed] 
31. Cunningham, D.; Danley, D.E.; Geoghegan, K.F.; Griffor, M.C.; Hawkins, J.L.; Subashi, T.A.; Varghese, A.H.; Ammirati, M.J.; Culp, J.S.; Hoth, L.R.; et al. Structural and biophysical studies of PCSK9 and its mutants linked to familial hypercholesterolemia. Nat. Struct. Mol. Biol. 2007, 14, 413-419. [CrossRef] [PubMed]

32. Llinas, P.; Le Du, M.H.; Gardsvoll, H.; Dano, K.; Ploug, M.; Gilquin, B.; Stura, E.A.; Menez, A. Crystal structure of the human urokinase plasminogen activator receptor bound to an antagonist peptide. Embo J. 2005, 24, 1655-1663. [CrossRef] [PubMed]

33. Ogiso, H.; Ishitani, R.; Nureki, O.; Fukai, S.; Yamanaka, M.; Kim, J.-H.; Saito, K.; Sakamoto, A.; Inoue, M.; Shirouzu, M.; et al. Crystal structure of the complex of human epidermal growth factor and receptor extracellular domains. Cell 2002, 110, 775-787. [CrossRef]

34. Usama, S.M.; Thavornpradit, S.; Burgess, K. Optimized Heptamethine Cyanines for Photodynamic Therapy. ACS Appl. Bio Mater. 2018, 1, 1195-1205. [CrossRef]

35. Usama, S.M.; Lin, C.-M.; Burgess, K. On the mechanisms of update of tumor-seeking cyanine dyes. Bioconjugate Chem. 2018. [CrossRef] [PubMed]

36. Sato, K.; Gorka, A.P.; Nagaya, T.; Michie, M.S.; Nakamura, Y.; Nani, R.R.; Coble, V.L.; Vasalatiy, O.V.; Swenson, R.E.; Choyke, P.L.; et al. Effect of charge localization on the in vivo optical imaging properties of near-infrared cyanine dye/monoclonal antibody conjugates. Mol. BioSyst. 2016, 12, 3046-3056. [CrossRef] [PubMed]

37. Nani, R.R.; Gorka, A.P.; Nagaya, T.; Kobayashi, H.; Schnermann, M.J. Near-IR light-mediated cleavage of antibody-drug conjugates using cyanine photocages. Angew. Chem. Int. Ed. 2015, 54, 13635-13638. [CrossRef] [PubMed]

Sample Availability: Samples of the compounds 1a-d are available from the authors.

(C) 2018 by the authors. Licensee MDPI, Basel, Switzerland. This article is an open access article distributed under the terms and conditions of the Creative Commons Attribution (CC BY) license (http://creativecommons.org/licenses/by/4.0/). 